\title{
Overlooking a potential hotspot at Great Barrier Island for the nationally endangered bottlenose dolphin of New Zealand
}

\author{
Sarah L. Dwyer ${ }^{1, *}$, Gabriela Tezanos-Pinto ${ }^{1}$, Ingrid N. Visser ${ }^{2}$, \\ Matthew D. M. Pawley ${ }^{1}$, Anna M. Meissner ${ }^{1}$, Jo Berghan ${ }^{3}$, Karen A. Stockin ${ }^{1}$ \\ ${ }^{1}$ Coastal-Marine Research Group, Institute of Natural and Mathematical Sciences, Massey University, Private Bag 102904, \\ North Shore, Auckland 0745, New Zealand \\ ${ }^{2}$ Orca Research Trust, PO Box 402043, Tutukaka 0153, New Zealand \\ ${ }^{3} 4$ Access Road, Kerikeri 0230, New Zealand
}

\begin{abstract}
Conservation initiatives are typically constrained by economic circumstances, a factor certainly true for marine mammal conservation in New Zealand. Most research in this field has been conducted following concerns over anthropogenic impacts on populations and has therefore been funded and/or driven by stakeholder interest. Bottlenose dolphins Tursiops truncatus are classified as 'Nationally Endangered' in New Zealand waters. Here, we present the first study on occurrence, site fidelity and abundance of this species off Great Barrier Island (GBI), a previously overlooked region within the home range of the North Island population. Dedicated boat-based photo-identification surveys were conducted monthly from 2011-2013, resulting in 1412 sighting records of 154 individuals. Dolphins were recorded during all months of the year, with a higher probability of encounter in deeper waters during summer and shallower waters during winter and spring. Group sizes (median $=35$, mean $=36$ ) were higher than previously reported for this population in other regions. Individual re-sighting patterns were variable; however, overall site fidelity was high (mean monthly sighting rate $=0.33$ ). A Robust Design approach resulted in seasonal fluctuations in abundance and temporary emigration. Based on a super-population estimate, 171 dolphins $(\mathrm{CI}=162-180)$ visited the area during 2011-2013. Our data suggest that GBI is a potential hotspot for bottlenose dolphins of the North Island population rather than a corridor to reach other destinations. We highlight the need for researchers, managers and funding agencies to consider the entire range of a population when conducting or funding research.
\end{abstract}

KEY WORDS: Photo-identification $\cdot$ Site fidelity $\cdot$ Home range $\cdot$ Hotspot $\cdot$ Population abundance $\cdot$ Mark-recapture $\cdot$ Survival $\cdot$ Robust Design $\cdot$ User-pays research $\cdot$ Tursiops truncatus

\section{INTRODUCTION}

Worldwide conservation efforts employed to date have typically relied on a triage system, whereby a species/population only receives protection after it has been demonstrated that there is an urgent requirement to do so (Hooker \& Gerber 2004). Often, management efforts instigated to conserve these en- dangered populations subsequently focus on the protection of key areas and habitats (e.g. Komdeur 1996, Clapham et al. 1999, Wright et al. 2008). However, optimal protection would need to encompass the population's year-round distribution, assuming that this is even known.

Most conservation initiatives are constrained by economic circumstances. In New Zealand, the major- 
ity of scientific evaluation of marine mammal species and populations has historically been driven by concerns about either incidental fisheries bycatch (common dolphin Delphinus sp.: Thompson et al. 2013; Hector's dolphin Cephalorhyncus hectori hectori: Slooten \& Lad 1991, Slooten 2007, Rayment \& Webster 2009; Maui's dolphin Cephalorhyncus hectori maui: Slooten et al. 2006; New Zealand sea lion Phocarctos hookeri: Chilvers et al. 2005, Chilvers 2008) or tourism effects (bottlenose dolphin Tursiops truncatus: Lusseau 2003, Constantine et al. 2004; common dolphin: Neumann \& Orams 2006, Stockin et al. 2008a; dusky dolphin Lagenorhynchus obscurus: Lundquist et al. 2012; Hector's dolphins: Bejder et al. 1999, Martinez et al. 2010; sperm whale Physeter macrocephalus: Richter et al. 2006). We use the term 'user-pays research' to refer to the type of system illustrated by these examples, whereby a stakeholder provides research funding to address specific conservation or management needs. As such, research objectives are often specifically based on industry-driven requirements. Although the appropriate feedback can be directly provided to industry stakeholders regarding any potential impacts, the system can be flawed if funding motives become limited over time towards certain research interests, populations or geographic regions.

Although the global conservation status of bottlenose dolphins is low risk 'Least Concern' (Hammond et al. 2012), the Mediterranean Sea and Fiordland (New Zealand) populations have been recognised as 'Vulnerable' (Bearzi et al. 2012) and 'Critically Endangered' (Currey et al. 2011), respectively. Coastal bottlenose dolphins occur in 3 geographically discrete populations in New Zealand waters (Baker et al. 2010), with low levels of gene flow among them (Tezanos-Pinto et al. 2009). Under the New Zealand Threat Classification System, the species was listed as 'Not Threatened' up until 2002 (Hitchmough 2002) and subsequently uplisted to 'Range Restricted' in 2005 (Hitchmough et al. 2007). A further reclassification to 'Nationally Endangered' in 2009 (Baker et al. 2010) was based on apparent declines in abundance in 2 of the 3 coastal populations, coupled with reports of high calf mortality (Currey et al. 2009, Tezanos-Pinto et al. 2013).

The coastal bottlenose dolphin population of the northern North Island (hereafter referred to as the North Island population) primarily ranges from Doubtless Bay to Tauranga (see Fig. 1) (Constantine 2002); although infrequent sightings of known indi- viduals outside of these areas have more recently extended the known range to the west coast of the North Island (Tezanos-Pinto et al. 2013). A decline in abundance has been reported for the Bay of Islands (BOI) (Tezanos-Pinto et al. 2013), where studies on bottlenose dolphins have formed the basis of our understanding of the North Island population. Research on the species in this region has primarily been driven by funding generated from dolphin tourism levies through the Department of Conservation (DOC), the government agency responsible for managing New Zealand's marine mammal species (e.g. Constantine \& Baker 1997, Constantine et al. 2003, Hartel et al. 2014). As such, research on this population has not only been heavily focused on tourism effects (e.g. Constantine 2001, Constantine et al. 2004), but perhaps more importantly, primarily restricted to the specific areas in which tourism is highly developed (BOI in the case of the North Island population). Consequently, while the North Island population has been extensively studied within the confines of BOI, there remains only one species-specific study published to represent other regions (i.e. the inner Hauraki Gulf; Berghan et al. 2008) within the greater home range of this population.

Great Barrier Island (GBI) is situated in the outer Hauraki Gulf and within the home range of the North Island population (Constantine 2002); however, previous marine mammal research efforts in the GBI region have been limited to large whale acoustics (Kibblewhite et al. 1967, Helweg 1998, McDonald 2006). No dedicated delphinid studies have been conducted in the GBI area, likely due to a combination of an absence of direct interest from stakeholders and the logistical constraints of fieldwork in this comparatively remote location. As such, no information is presently available within the scientific literature describing bottlenose dolphins or indeed any other delphinid off GBI.

Here we present the first information about bottlenose dolphins off the west coast of GBI. We describe occurrence, examine factors affecting the probability of encountering bottlenose dolphins at GBI, and assess group dynamics. Using individual photo-identification (Würsig \& Jefferson 1990) we investigate site fidelity and estimate abundance, demographic parameters and temporary emigration rates. Our overall objective was to assess the importance of GBI, an overlooked area within the home range of a nationally endangered species, in order to inform current conservation management strategies. 


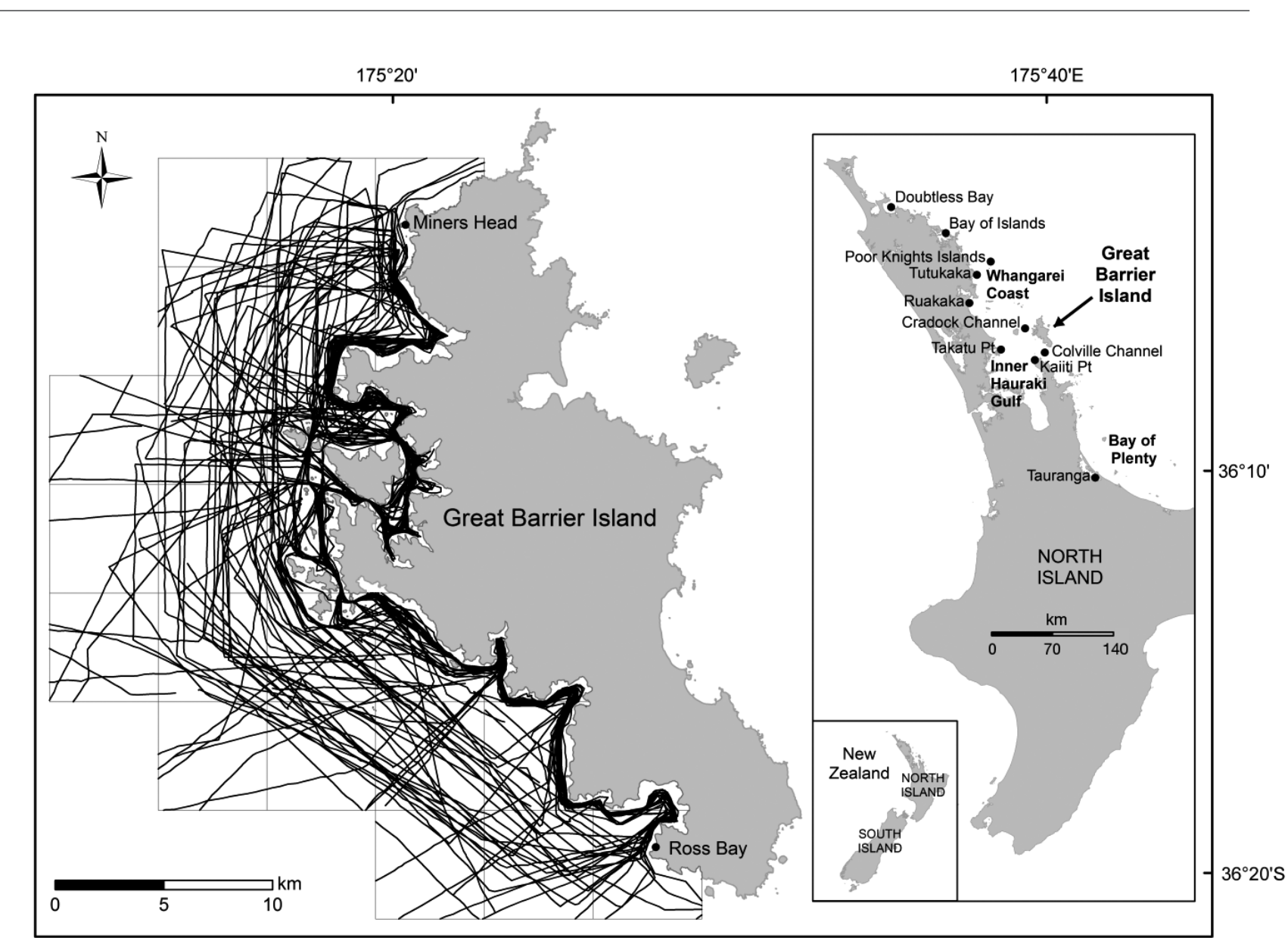

Fig. 1. Survey tracks off the west coast of Great Barrier Island, New Zealand, between January 2011 and January 2013. Only on-effort tracks (black lines) are displayed. Grey lines show the $5 \times 5 \mathrm{~km}$ grid cells. Inset: Location of Great Barrier Island and other places referred to in the text in relation to the North Island of New Zealand

\section{MATERIALS AND METHODS}

\section{Study area}

GBI $\left(36^{\circ} 10^{\prime} \mathrm{S}, 175^{\circ} 23^{\prime} \mathrm{E}\right)$, situated approximately $80 \mathrm{~km}$ northeast of Auckland city $\left(36^{\circ} 51^{\prime} \mathrm{S}, 174^{\circ} 46^{\prime} \mathrm{E}\right)$, is located within the outer Hauraki Gulf, North Island, New Zealand (Fig. 1, inset). The west coast of GBI, adjacent to Cradock Channel in the north $\left(36^{\circ} 12^{\prime} \mathrm{S}\right.$, $\left.175^{\circ} 11^{\prime} \mathrm{E}\right)$ and Colville Channel in the south $\left(36^{\circ} 23^{\prime} \mathrm{S}\right.$, $175^{\circ} 25^{\prime} \mathrm{E}$ ), is characterised by numerous shallow embayments and a predominantly rocky shoreline. The study site ${ }^{\mathbf{1}}$ included all waters up to a distance of $10 \mathrm{~km}$ offshore between Miners Head in the north and Ross Bay in the south (Fig. 1) and therefore en-

\footnotetext{
1 The study site was limited to the research vessel operating area, which was permitted in accordance with the Maritime New Zealand Safe Ship Management system for commercial vessels. For GBI, the operating area for the research vessel was restricted to waters off the western side of the island.
}

compassed $\sim 500 \mathrm{~km}^{2}$. Water depths in the study area are relatively shallow and reach a maximum of $90 \mathrm{~m}$ (Chart NZ 522, Land Information New Zealand). With a land area of $285 \mathrm{~km}^{2}, \mathrm{GBI}$ is the largest of New Zealand's northern offshore islands, but has a low human population density, and $68 \%$ of the land is administered by DOC (Norgrove \& Jordan 2006). Most of the west coast remains uninhabited and there are currently no commercial marine mammal tourism operations at GBI.

\section{Data collection}

Survey data were collected across all austral seasons between January 2011 and January 2013. When possible (i.e. when weather and sea conditions permitted), monthly research trips averaging $4 \mathrm{~d}$ in duration were made to GBI. Boat-based surveys were conducted on the research vessel 'Te Epiwhania', a $5.5 \mathrm{~m}$ aluminium boat powered by a $100 \mathrm{hp} 4$-stroke 
outboard engine. A non-systematic survey design was employed, with survey tracks selected based on prevailing weather, sea conditions, and on the extent any particular area had been previously surveyed within that month. Where possible, routes were selected to achieve equal survey coverage of the west coast and to include both nearshore and offshore waters up to $10 \mathrm{~km}$ from land within any given month. Efforts were also made to survey the latitudinal extent of the GBI west coast in order to cover both northern and southern regions in any given day. Surveys were conducted in conditions of Beaufort Sea State 3 or less. Time spent travelling along survey tracks searching for dolphins, with vessel speed maintained at 10 knots, was classified as 'on effort'.

Whilst on effort, 2 experienced observers continuously scanned to the horizon. Dolphins were detected by naked eye and/or binoculars $(10 \times 50$ magnification) using scanning methodology (Mann 1999). Visual cues to indicate dolphin presence included splashing, water disturbance and sighting of dorsal fins (Stockin et al. 2008b). Once the research boat left the survey track to approach a group of dolphins, the survey mode switched to 'off effort' until returning to the track to resume searching for dolphins. Off-effort mode also included all other occasions when the research vessel was away from the survey track (e.g. returning to harbour due to deteriorating sea conditions).

When a dolphin group was detected, the research vessel approached to within $50 \mathrm{~m}$ and commenced data collection. Water depth $( \pm 0.1 \mathrm{~m})$ was measured using an on-board depth sounder at the location where the group was first sighted. All observational and environmental data were collected using an XDA Orbit II Windows Mobile device. CyberTracker version 3 software (Steventon et al. 2002) was programmed for logging observational data (e.g. group size) and to record the GPS position every $60 \mathrm{~s}$ throughout the survey day.

A group of dolphins was defined as any number of individuals observed in apparent association, moving in the same general direction and often, but not always, engaged in the same activity (Shane 1990). Group size was recorded at sea using minimum, maximum and best estimate counts and was later confirmed or amended using photo-identification data. If all individuals in the group were not photographed (e.g. due to time constraints), the best estimate was selected for group size.

Age class definitions follow those previously described for the North Island population (Constantine 2002, Tezanos-Pinto 2009):
- Neonate: presence of obvious white dorso-ventral foetal folds and often uncoordinated upon surfacing to breathe; typically observed up to 3 mo old

- Calf: approximately half or less the size of an adult, closely associated with an adult and often swimming in the 'infant position'

- Juvenile: approximately two-thirds the size of an adult and frequently observed in association with the mother but not in the 'infant position'

- Adult: fully grown dolphin of $>3.0 \mathrm{~m}$ in length.

The number of neonates, calves and juveniles was estimated visually at sea using minimum, best and maximum counts and was later confirmed or amended using photo-identification data.

Photo-identification of individual bottlenose dolphins was conducted for all groups following standard methods (Würsig \& Jefferson 1990) using a Canon 7D or 400D camera fitted with 100-400 or 70$300 \mathrm{~mm}$ lenses, respectively. Attempts were made to photograph all individuals in the group, regardless of the degree of mark distinctiveness of the fin. Both left and right sides of the dorsal fin were photographed where possible.

After observational data were logged and photoidentification completed, the research vessel returned to the survey route and resumed on-effort searching for independent groups (i.e. groups separated spatially and temporally as confirmed by no photographic matches). Multiple independent groups could therefore be observed during any one given survey.

\section{Data analysis}

Austral seasons were defined as summer (December to February), autumn (March to May), winter (June to August) and spring (September to November) in accordance with previous studies on this population (Constantine 2002, Berghan et al. 2008, Tezanos-Pinto 2009). Both on- and off-effort sighting data were included in analyses unless otherwise stated. Statistical analyses were carried out using SPSS v.20 for investigations into group composition and seasonal patterns in occurrence according to depth. Since data were not normally distributed, Kruskal-Wallis and Mann-Whitney $U$-tests were used to test for significance at $\mathrm{p}<0.05$.

\section{Probability of encounter}

Logistic regression was used to model the probability of encountering a bottlenose dolphin. A grid 
of 27 cells of $5 \times 5 \mathrm{~km}$ (Fig. 1) was created in ArcGIS v.10.0, and presence or absence of dolphins was recorded for each cell sampled per survey day. Only on-effort sightings were considered for the analysis, which was carried out in $\mathrm{R}$ version 3.0.1 (R Development Core Team 2013). Search effort was calculated as on-effort $\mathrm{km}$ per grid cell per survey day using Geospatial Modelling Environment version 0.7.2.0 tools (Beyer 2012). Depth data for cells where dolphins were recorded (i.e. presence) were collected using the onboard depth sounder and within $100 \mathrm{~m}$ of the position of the group when first sighted. For cells where dolphins were not encountered (i.e. absence), depth was retrieved at the midpoint of the track segment in each cell surveyed using the NIWA Hauraki Gulf bathymetric dataset (Mackay et al. 2012). Daily sea surface temperature (SST) data were obtained from the Physical Oceanography Distributed Active Archive Centre (PO.DAAC, NASA Jet Propulsion Laboratory, Pasadena, California, USA) at a $1 \mathrm{~km}$ spatial scale and subsequently averaged over each grid cell. Depth (in m), SST, season (a factor with 4 levels), time of day of the survey, effort ( $\mathrm{km}$ traversed in the grid) and Beaufort sea state were fit as covariates in the initial model. Variables were dropped or retained from the initial model by comparing the reduction in deviance using a chi-square test. Confidence intervals for each parameter were calculated assuming asymptotic normality.

\section{Photo-identification}

Photographs included in analysis and in the subsequent Great Barrier Island Bottlenose Dolphin Catalogue (S. L. Dwyer unpubl. data) were selected based on 4 criteria described in Berghan et al. (2008), to account for angle, focus, relative size and contrast of the fin. Following Tezanos-Pinto et al. (2013), only excellent and good quality photographs were included in the analyses. Nicks and notches in the dorsal fin were used in conjunction with secondary features (i.e. scarring, including tooth rake marks) to identify and match individuals (Würsig \& Jefferson 1990). All matching of images was performed by S. L. Dwyer and cross-checked by 2 experienced researchers. Sighting information was recorded in a database for each identified individual. Mother-calf associations were confirmed using photographs from at least 2 independent encounters (Tezanos-Pinto 2009).

\section{Site fidelity}

Site fidelity at GBI was investigated using monthly (MSR) and seasonal sighting rates (SSR), a methodology described by Parra et al. (2006). These were calculated by expressing the number of months a dolphin was identified as a proportion of the total number of months in which at least 1 survey was conducted, and the number of seasons a dolphin was identified as a proportion of the total seasons surveyed, respectively (Parra et al. 2006, Cagnazzi et al. 2011). MSR could therefore range between 0.05 and 1.0, for individuals sighted in only 1 survey month or in all 20 survey months, respectively; similarly, SSR could range between 0.25 and 1.0 for individuals sighted in only 1 season or in all 4 seasons, respectively. To minimise the chance of dependence in the data, only 1 sighting record per individual per day was used (Parra et al. 2006, Cagnazzi et al. 2011). Based on previously published high and low mean MSR values for dolphins (e.g. high MSR $=0.26$ : Cagnazzi et al. 2011; low MSR =0.10: Parra et al. 2006), individuals were subsequently and conservatively (i.e. using higher minimum values than those previously reported) classified into 1 of 3 categories based on MSR and SSR: (1) occasional visitors (MSR $\leq$ 0.15 , irrespective of SSR), (2) moderate users $(0.15<$ MSR $<0.35$, SSR $\geq 0.5$ ), or (3) frequent users (MSR $\geq$ 0.35 , SSR $\geq 0.75$ ). Therefore, frequent users were defined as animals sighted on average at least once every 3 mo and observed during at least 3 seasons of the year. A weighted ratio of the total number of sighting records per unique individual was calculated for each category to assess the relative changes by season.

In order to assess whether dolphins sighted at GBI were also recorded outside the study area, each individual in the Great Barrier Island Bottlenose Dolphin Catalogue was cross-referenced (using standard photo-identification methods described herein) with images and published records of bottlenose dolphins photographed in 3 other regions of the North Island population home range (Fig. 1, inset):

(1) Inner Hauraki Gulf (south of GBI). All waters south of a line between Takatu Point on the mainland and Kaiiti Point on the Coromandel Peninsula. Data from 2000 to 2006 (Hauraki Gulf Bottlenose Dolphin Catalogue, HGBDC $)^{\underline{2}}$ were combined with data from 2009 to 2013 (S. L. Dwyer unpubl. data).

\footnotetext{
$\underline{2}$ Hauraki Gulf Bottlenose Dolphin Catalogue: J. Berghan, K. Algie, K. Stockin, N. Wiseman \& G. Tezanos-Pinto, unpubl. data
} 
(2) Bay of Plenty (south of GBI). Coastal Tauranga region up to $40 \mathrm{~km}$ offshore. Photographs were analysed from data collected during dedicated surveys conducted between 2010 and 2013 (A. M. Meissner unpubl. data).

(3) Whangarei Coast (north of GBI). Coastal waters between Tutukaka and Ruakaka, including the Poor Knights Islands located $20 \mathrm{~km}$ offshore. Bottlenose dolphins were photographed opportunistically on 20 occasions between 2002 and 2011 (I. N. Visser unpubl. data).

\section{Abundance, temporary emigration and survival estimates}

Mark-recapture techniques using the Robust Design (Pollock 1982, Kendall et al. 1997) were used to estimate abundance, demographic parameters and temporary emigration rates. The Robust Design incorporates open sampling events called 'primary periods' within which are a number of closed 'secondary periods' (Pollock 1982). Closure is assumed within primary periods but not between them. To fulfil this assumption, the Robust Design relies on secondary periods being close together temporally (Kendall 2004). Bottlenose dolphins along the North Island have variable patterns of residency and home ranges (Constantine 2002, Tezanos-Pinto 2009) that may result in unequal capture probabilities between individuals (Tezanos-Pinto et al. 2013). The Robust Design allows for temporary emigration, resulting in a useful model to estimate abundance for species that move in and out of the study area. The Schwarz and Arnanson 'super-population' parameterization of the Jolly-Seber model (Schwarz \& Arnanson 1996, Williams et al. 2002) was implemented to estimate the total number of dolphins that visited GBI during 2011-2013 (i.e. the super-population).

\section{Data organization}

A 'sighting' refers to an individual identification photograph obtained during an encounter with a uniquely identified dolphin (ID) and the associated data collected during such an encounter (e.g. date, GPS position, group composition). The complete individual sighting record constitutes the encounter history of a dolphin. Individual photo-identification data were structured for the Robust Design by seasons fitting a hierarchical structure (primary samples or sessions, secondary samples within primary sam- ples) to gain an understanding of the number of dolphins present at GBI in each season and estimate rates of apparent survival and temporary emigration between seasons. For this reason, the dataset employed for abundance estimates is different to the site fidelity dataset that includes the full sighting records for GBI. Sighting data were selected in closely adjacent clusters of days with discrete breaks between clusters, to implement the selection of secondary (i.e. sampling days) and primary samples (sessions). Secondary periods were composed of near-consecutive day-surveys with a minimum of 2 and a maximum of 5 day-surveys (median 3 day-surveys), and primary samples were separated by a minimum of $56 \mathrm{~d}$ (0.15 decimal years) and a maximum of $112 \mathrm{~d}(0.31$ decimal years) between their mid dates (median $91 \mathrm{~d}$ or 0.25 decimal years).

Seasonal data for POPAN were selected to estimate the total number of dolphins that used the area during the course of the study (the super-population) by considering one sighting per season for each dolphin (Williams et al. 2002, Nichols 2005), meaning that the dolphin was either absent (0) or present (1) during that season.

\section{Robust Design model}

Pollock's Robust Design models were run in MARK version 5.1 (White \& Burnham 1999). The intervals between seasons were specified in decimal years between their mid dates to obtain consistent estimates of survival. For each season, we estimated the capture probability $(p)$ and abundance $(\hat{N})$ of dolphins at GBI. From the intervals between seasons, we estimated the apparent survival probability $(\phi)$, the probability that an animal is outside the study area on a sampling occasion given that it was inside the study area on the previous occasion $\left(\gamma^{\prime \prime}\right)$, and the probability that an animal is outside the study area on a sampling occasion given that it was outside the study area on the previous occasion $\left(\gamma^{\prime}\right.$; Kendall et al. 1995, 1997). Models were considered with temporal variation in capture probabilities between ( $s=$ seasons or primary samples), within ( $t=$ daily surveys within a season, secondary samples), and both between and within primary periods $\left(s^{*} t\right)$. Recapture probabilities were constrained to equal capture probabilities on each occasion for all models because there was no evidence of a behavioural effect. We fitted models with no temporary emigration $\left(\gamma^{\prime \prime}=\gamma^{\prime}=0\right)$, random $\left(\gamma^{\prime \prime}=\gamma^{\prime}\right)$ and Markovian temporary emigration $\left(\gamma^{\prime \prime} \neq \gamma^{\prime}\right)$ (Huggins 1991, Kendall et al. 1997). To provide 
parameter identifiability for the Markovian models, we either constrained apparent survival ( $\phi$ ) to be constant or added a constraint (session $k=\operatorname{session} k-1$ ) resulting in the last 2 parameters in the time series set to equal (Kendall et al. 1997). We used Akaike's Information Criterion (AIC) to evaluate model fit. The best fitting model was identified as having the lowest AICc (Burnham \& Anderson 2004).

\section{POPAN super-population models}

A 'super-population' approach was applied in POPAN as implemented in MARK, to estimate the abundance of the 'larger' population that used the area during the course of the study. The approach is based on a re-parameterization of the Jolly-Seber (JS) model with an additional parameter $\hat{N}_{\text {super }}$ that denotes the size of the 'super-population'. Models were considered with constant (.) and temporal variation $(t)$ in capture probabilities between seasons. We added a constraint to the first 2 and the last 2 capture probabilities to provide parameter identifiability for all models (Cooch \& White 2011).

\section{Mark ratio}

As with other wild populations of dolphins, not all individuals bear sufficient marks for individual recognition. To account for these unmarked dolphins at GBI, we estimated a mark ratio (Jolly 1965). High quality photographs (only excellent and good quality) were counted including all age-classes to estimate the ratio of individually identifiable dolphins (i.e. marked animals) during 2011-2013. Only those encounters in which all dolphins, irrespective of their marks, were photographed several times were included for this estimate. The proportion of marked dolphins $\left(P_{\mathrm{m}}\right)$ was estimated (Gormley et al. 2005) as the ratio between the number of marked dolphins and the total number of dolphins observed on each survey, averaged over all surveys (Cantor et al. 2012). $P_{\mathrm{m}}$ and its variance (Gormley et al. 2005) were estimated as follows:

$$
\hat{P}_{\mathrm{m}}=\frac{\sum_{i=1}^{k} \frac{I_{i}}{T_{i}}}{k}, \operatorname{var}\left(\hat{P}_{\mathrm{m}}\right)=\left(\sum_{i=1}^{k} \frac{\hat{P}_{\mathrm{m}_{i}}\left(1-\hat{P}_{\mathrm{m}_{i}}\right)}{T_{i}}\right) / k^{2}
$$

where $I_{i}$ is the number of identifiable (i.e. marked) dolphins per survey, $T_{i}$ is the total number of dolphins sighted during the $i^{\text {th }}$ survey day and $k$ is the total number of survey days for which $I / T$ was cal- culated $(k=34)$, for each $\hat{P}_{\mathrm{m}_{i}}=I_{i} / T_{i}$. Abundance estimates were scaled by the mark-ratio to obtain the total abundance $\hat{N}_{\text {total }}$ (Williams et al. 1993) as follows:

$$
\hat{N}_{\text {total }}=\hat{N}_{\mathrm{m}} / \hat{P}_{\mathrm{m}}
$$

where $\hat{N}_{\mathrm{m}}$ is the abundance of marked dolphins. The variance (var) and standard error (SE) of $\hat{N}_{\text {total }}$ were calculated (Wilson et al. 1999) as follows:

$$
\begin{aligned}
& \operatorname{var}\left(\hat{N}_{\text {total }}\right)=\left(\hat{N}_{\text {total }}\right)^{2}\left[\operatorname{var}\left(\hat{N}_{\mathrm{m}}\right) /\left(\hat{N}_{\mathrm{m}}\right)^{2}+\operatorname{var}\left(\hat{P}_{\mathrm{m}}\right) /\left(\hat{P}_{\mathrm{m}}\right)^{2}\right] \\
& \operatorname{SE}\left(\hat{N}_{\text {total }}\right)=\sqrt{\operatorname{var}\left(\hat{N}_{\text {total }}\right)}
\end{aligned}
$$

Log-normal confidence intervals were calculated (Burnham et al. 1987) as follows:

$$
\begin{aligned}
& \hat{N}_{\text {lower }}=\hat{N}_{\text {total }} / C \text { and } \hat{N}_{\text {upper }}=\hat{N}_{\text {total }} \times C, \\
& \text { where } C=\exp \left(z_{\alpha / 2} \sqrt{\log _{e}\left\{1+\left[\operatorname{cv}\left(\hat{N}_{\text {total }}\right)\right]^{2}\right\}}\right)
\end{aligned}
$$

where $\hat{N}_{\text {lower }}$ is the lower bound of the confidence interval, $\hat{N}_{\text {upper }}$ is the upper bound of the confidence interval, $z_{\alpha / 2}$ is the normal deviate, $\alpha=0.05$ and $\mathrm{cv}$ is the coefficient of variation.

\section{Goodness of fit tests and model selection}

The Robust Design does not have a goodness of fit test; however, because this method is a combination of open and closed models, traditional tests can be applied. Consequently, each session was tested for closure using CloseTest (Stanley \& Burnham 1999). A Cormack-Jolly-Seber (CJS) framework was used to carry out goodness of fit tests (TEST $2 \mathrm{CT}$ and CL, and TEST 3 SM and SR) in U-CARE version 2.2 (Choquet et al. 2005) and evaluate potential violations of assumptions.

\section{RESULTS}

Between January 2011 and January 2013, over $4000 \mathrm{~km}$ were surveyed off the west coast of GBI (Fig. 1) during 71 survey days across 20 mo. A total of 44 independent groups of bottlenose dolphins were recorded, 36 encountered on effort and 8 off effort (Table 1). Photo-identification effort at GBI totalled $78.2 \mathrm{~h}$ during 37 survey days across all seasons. A total of 1412 sighting records (i.e. sighting of an identified individual on a discrete day) of 154 individuals photographed at GBI were used in the analyses. Individual sighting frequencies ranged from 1 to 27 (mean $=9.17$, $\mathrm{SD}=7.93)$. 
Table 1. Summary of bottlenose dolphin Tursiops truncatus encounters and survey effort by season (Summer: Dec-Feb; Autumn: March-May; Winter: Jun-Aug; Spring: Sep-Nov) and depth category at Great Barrier Island, New Zealand, between January 2011 and January 2013. Groups encountered: on-effort totals for all years combined (off-effort totals in parentheses); Sighting records: total number of individual dolphin sighting records for a discrete day, as confirmed by photographic matches; Unique individuals: number of unique individuals identified in that season. Survey effort includes on-effort km spent actively searching for dolphins; time spent with dolphins and transiting while off-effort is not included

\begin{tabular}{|lcccccccccccccc|}
\hline \multirow{2}{*}{ Season } & \multirow{2}{*}{$\begin{array}{c}\text { Groups } \\
\text { encountered }\end{array}$} & \multirow{2}{*}{$\begin{array}{c}\text { Sighting } \\
\text { records }\end{array}$} & $\begin{array}{c}* \\
\text { Undique }\end{array}$ & \multicolumn{1}{c}{ individuals } & $0-9$ & $10-19$ & $20-29$ & $30-39$ & $40-49$ & $50-59$ & $60-69$ & $70-79$ & $80-89$ & Total \\
\hline Summer & $10(3)$ & 524 & 100 & 26.4 & 97.9 & 142.4 & 225.4 & 221.8 & 155 & 89.4 & 65.3 & 34.7 & 1058.3 \\
Autumn & $9(2)$ & 217 & 116 & 31.4 & 113.8 & 166 & 220.3 & 228.5 & 190 & 131.4 & 65.2 & 13.5 & 1160.1 \\
Winter & $7(2)$ & 237 & 77 & 36.3 & 121.6 & 161.4 & 204.6 & 191.1 & 127.3 & 55.1 & 73 & 27 & 997.4 \\
Spring & $10(1)$ & 434 & 98 & 33.7 & 101.9 & 143.8 & 185.4 & 150.3 & 86.7 & 46.4 & 50.7 & 2.4 & 801.3 \\
Total & $36(8)$ & 1412 & 154 & 127.8 & 435.2 & 613.6 & 835.7 & 791.7 & 559 & 322.3 & 254.2 & 77.6 & 4017.1 \\
\hline
\end{tabular}

\section{Occurrence}

Bottlenose dolphins were sighted at GBI during all months of the year. Despite extensive effort up to $10 \mathrm{~km}$ offshore (Fig. 1), dolphins were found within 1 and $2 \mathrm{~km}$ of the coast for 84 and $96 \%$ of encounters, respectively. Groups were encountered across a range of water depths from 2 to $57.4 \mathrm{~m}$ (mean $=22.88$, $\mathrm{SD}=15.88, \mathrm{n}=44$ ), with surveys conducted in depths of up to $86 \mathrm{~m}$ (Table 1, Fig. 2). Since areas with water depths of $>60$ m were only available for surveying in the northern region of the study area, these depths received less effort. There was a significant difference in depth according to season (Kruskal-Wallis $H=19.10, \mathrm{df}=3, \mathrm{p}<0.001, \mathrm{n}=44)$, with shallower waters used during spring (median $=6.60, \mathrm{IQR}=4.6-$

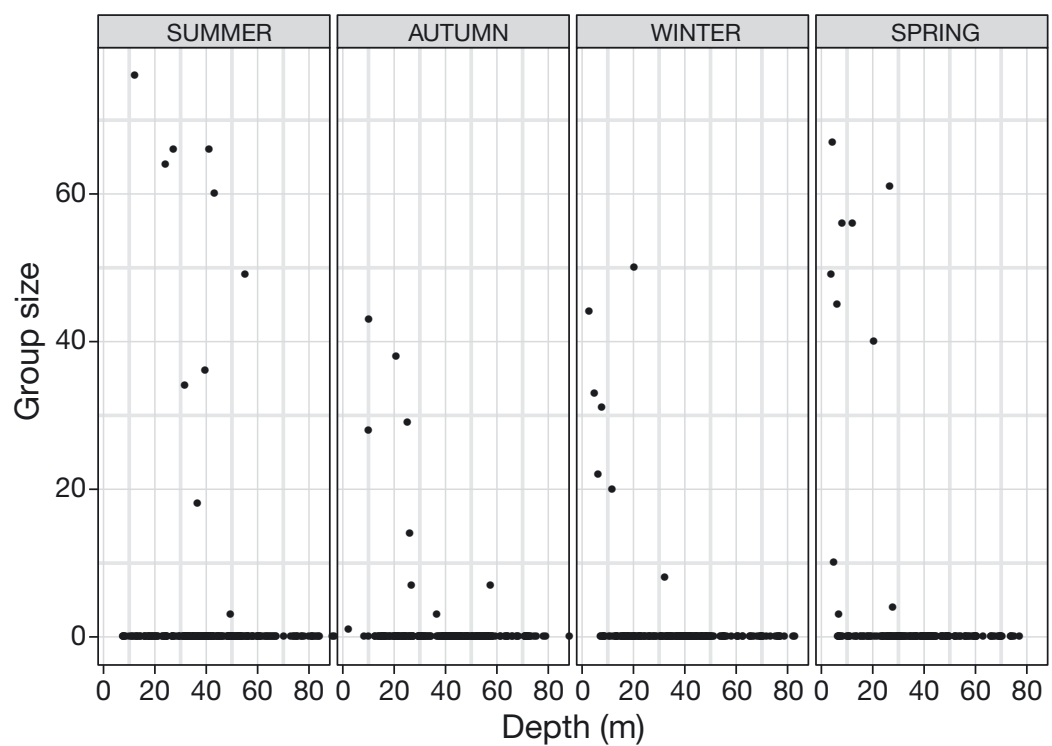

Fig. 2. Group size of bottlenose dolphins Tursiops truncatus (on-effort sightings only) at Great Barrier Island, New Zealand, varies with depth and season. Black dots at zero group size indicate non-detections during sampling of a grid cell
$20.2)$ and winter $($ median $=11.50, \mathrm{IQR}=5.4-26.1)$ and deeper waters used during summer (median $=$ $39.40, \mathrm{IQR}=29.1-43.9$ ).

\section{Probability of encounter}

The final logistic model found evidence that the probability of encounter depended only on season and depth (although these 2 variables interacted). There was no evidence that the 'effort' variable $(\mathrm{km}$ traversed within the grid cell on that sample occasion) was important, however it was retained in the final logistic model. There was strong evidence $(\mathrm{p}=$ 0.0016) of an interaction between depth and season, with the effect of depth dependent upon season. Corresponding with the results of the nonparametric tests, the model suggested an increased probability of encountering dolphins in deeper water (further from shore) in summer (Fig. 3). Additionally, the probability of encountering dolphins in shallow water (closer to shore) was highest in winter and spring (Fig. 3). Overall, the probability of encountering dolphins was highest in waters of less than $20 \mathrm{~m}$ depth (Fig. 3).

\section{Group dynamics}

Group size ranged from 1 to 82 individuals $($ median $=35$, mean $=36.39$, $\mathrm{SD}=23.36, \mathrm{n}=44$ ) and varied with depth and season (Fig. 2). A relatively large proportion (32\%) of groups consisted of $\geq 50$ individuals, all of which 


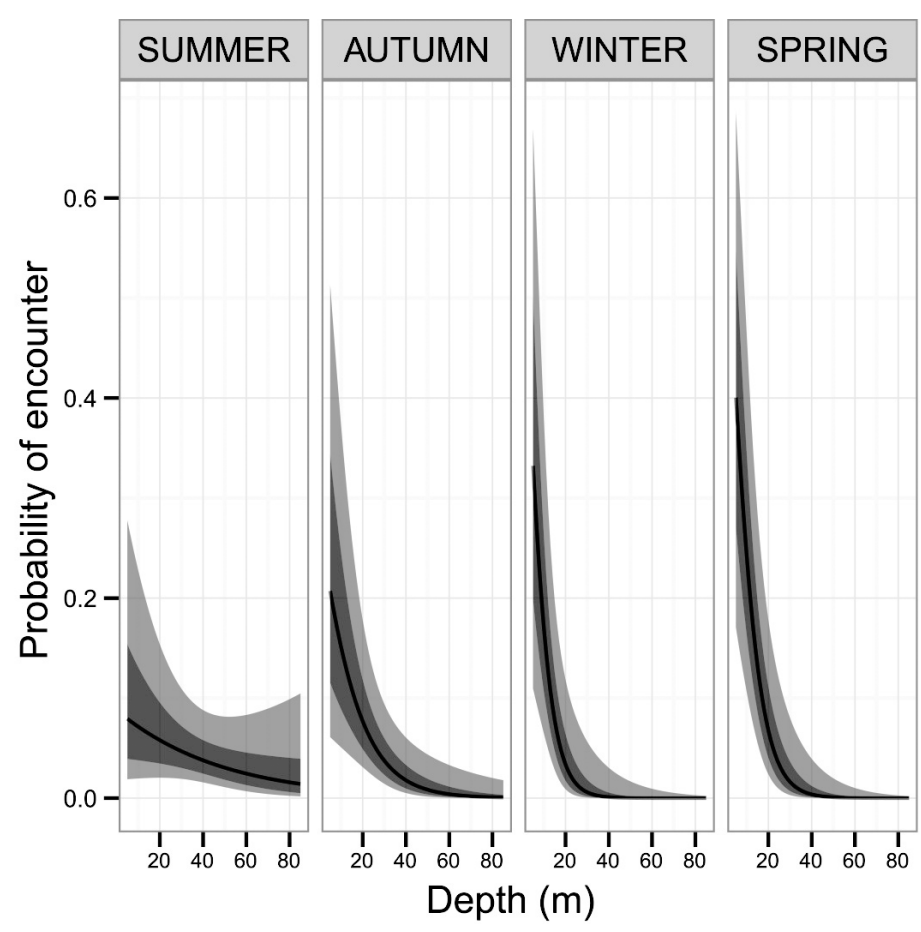

Fig. 3. Model results showing the interaction between depth and season on the probability of encountering bottlenose dolphins Tursiops truncatus at Great Barrier Island, New Zealand. Black line: average probability; darker and lighter shading: $1 \mathrm{SE}$ and $2 \mathrm{SE}$ intervals, respectively

were recorded in the southern region of the study area (Fig. 4) and primarily during spring and summer $(86 \%)$. Conversely, all small groups of $<10$ individuals $(18 \%)$ were recorded in the northern region (Fig. 4). A solitary dolphin was encountered during autumn and the largest group size $(\mathrm{n}=82$, as confirmed by photo-identification) was recorded during spring. Larger groups were sighted more frequently in spring and summer, and smaller groups were more prevalent in autumn and winter (Fig. 2). Two independent groups, confirmed by no photographic matches, were observed on the same survey day on 7 occasions. This included 109 individuals recorded at GBI on 18 February 2012 in 2 groups of 60 and 49 dolphins, separated by a distance of $19.4 \mathrm{~km}$. The majority of groups (82\%) contained immature dolphins. Group size (comparing only the number of adults within groups) was significantly higher (Mann-Whitney $U=$ $384.50, \mathrm{p}<0.001)$ in groups containing neonates or calves (median $=40, \mathrm{IQR}=28.5-52.3$ ) than groups containing only adults or adults and juveniles (median $=8, \mathrm{IQR}=$ 3.0-22.0). Groups with neonates and calves were therefore, on average, 5 times the size of groups with only adults or adults and juveniles. All adult-only groups contained $<22$ individuals (median $=7$, $\mathrm{SD}=7.42$ ).

Neonates and calves were observed across all seasons in $70 \%$ of groups. Where present, the number

Fig. 4. Initial sighting locations of bottlenose dolphin Tursiops truncatus groups encountered off Great Barrier Island, New Zealand, between January 2011 and January 2013. White circles: groups sighted on effort; black diamonds: off-effort sightings; grey shading: survey effort per $5 \times 5 \mathrm{~km}$ grid cell; dashed and solid lines: 50 and $100 \mathrm{~m}$ isobath, respectively 
of neonates in groups ranged from 1 to $4(\mathrm{SD}=1.15)$ and number of calves ranged from 1 to 9 ( $\mathrm{SD}=2.47$ ). Forty-three percent of groups contained at least one neonate, with the highest proportion of these groups encountered during summer (54\%) followed by spring (26\%) and autumn (16\%). Only one group was recorded with a neonate during winter. Parturition was not directly observed in the field; however, very young neonates were observed at GBI. For example, individual TM027 was recorded 27 times without a calf between 26 January 2011 and 28 December 2012 before being photographed with a neonate on 2 January 2013. During the study, 12 photo-identified adults were recorded consistently associated with neonates.

\section{Photo-identification}

Bottlenose dolphins were encountered during 19 out of 20 survey months. The discovery curve (Fig. 5) showed a steep ascent during early surveys before reaching a plateau in May 2012, with only 8 new individuals identified after this plateau during the final quarter of the study. Thirty-five dolphins $(23 \%)$ were sighted only once in the study area; however, a larger proportion of individuals $(37 \%, \mathrm{n}=57)$ were sighted $\geq 10$ times. Most re-sighted individuals (87\%, $\mathrm{n}=134$ ) were recorded in the study area in more than 1 year. The total number of individual sighting records in summer and spring were double those of autumn and winter (Table 1), in part due to the higher proportion of large group sizes observed in summer and spring (Fig. 2).

\section{Site fidelity}

Relative to the total number of months surveyed, bottlenose dolphins showed varying degrees of site fidelity to the west coast of GBI (Fig. 6). Higher proportions of both occasional visitors (41\%) and frequent users $(40 \%)$ and a lower number of moderate users $(19 \%)$ were observed. Overall, site fidelity was relatively high (mean $\mathrm{MSR}=0.33, \mathrm{SE}=0.022$, range $0.05-0.85)$. Over $32 \%$ of all identified individuals were sighted in more than $50 \%$ of the total survey months. SSR was also high (mean $=0.70, \mathrm{SE}=0.025$; Fig. 6), with 117 individuals (76\%) sighted in the study area during at least 2 different seasons. Just under half $(44 \%)$ of all identified individuals were recorded at GBI in all 4 seasons. Using a weighted ratio of the total number of sighting records per unique identified individual, the highest proportion of occasional visitors and frequent users per season were observed during autumn (30\%; Fig. 7) and winter $(63 \%$; Fig. 7), respectively.

The majority $(85 \%)$ of individuals identified at GBI were recorded in at least one of the other regions within the North Island home range for which photo-identification data were available (Table 2). Sixteen individuals were recorded in all of these regions. Unsurprisingly, there were a high number of matches $(\mathrm{n}=115)$ to the nearby inner Hauraki Gulf. Since all frequent users of GBI (n = 61) were sighted in at least one neighbouring region, even individuals regularly using GBI waters left the area at least seasonally to visit other regions up to $200 \mathrm{~km}$ away.

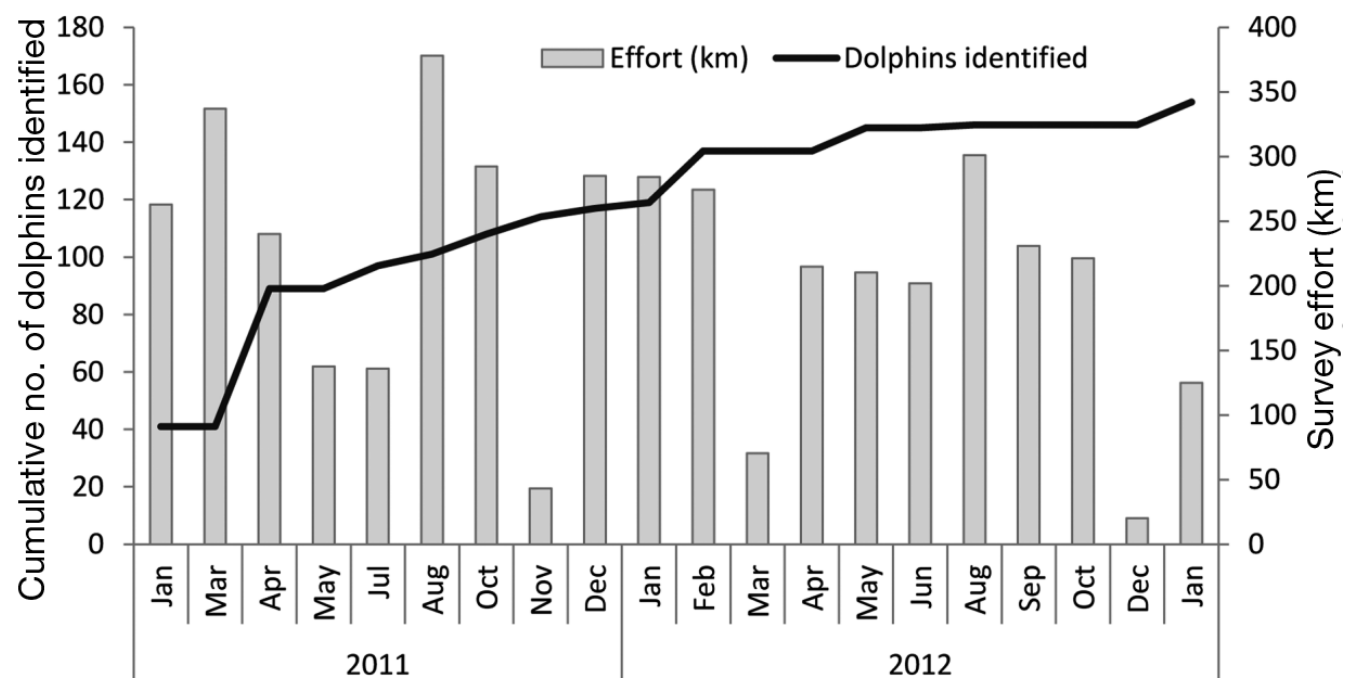

Fig. 5. Discovery curve of bottlenose dolphins Tursiops truncatus off Great Barrier Island, New Zealand, with cumulative number of individuals photo-identified per survey month between January 2011 and January 2013. Bars represent the number of on-effort km spent searching for dolphins (see 'Materials and methods') 


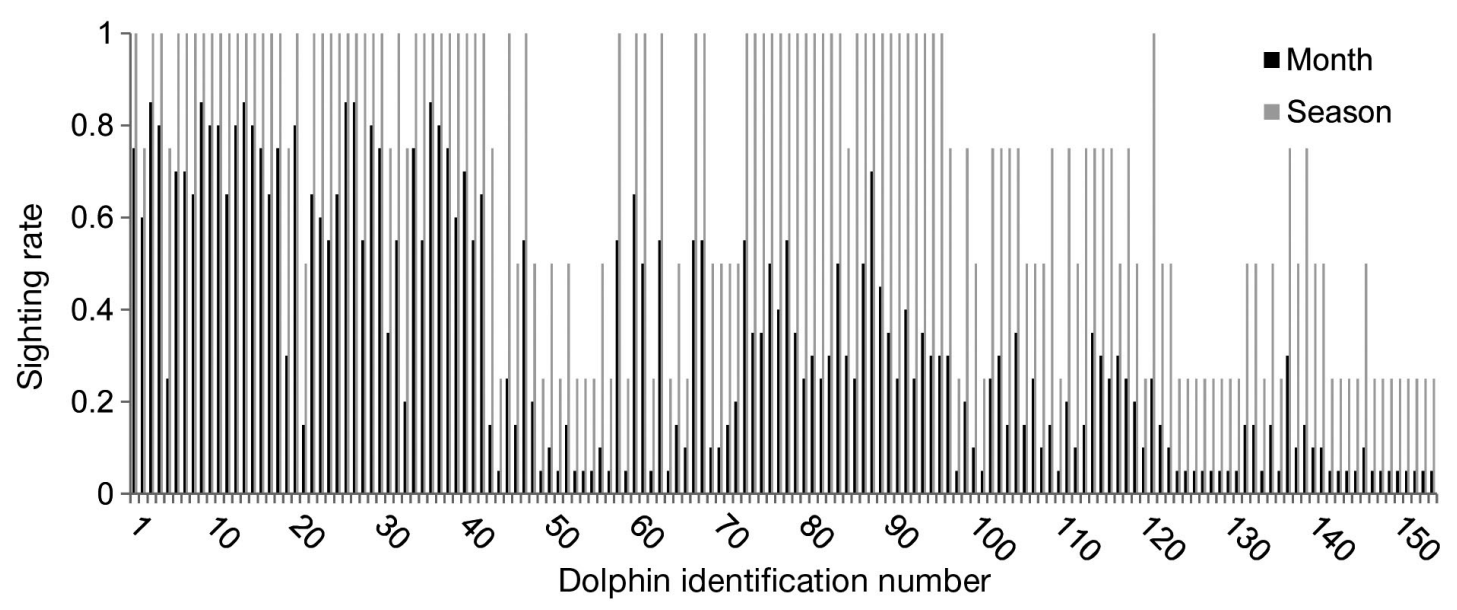

Fig. 6. Monthly and seasonal sighting rates of bottlenose dolphins Tursiops truncatus at Great Barrier Island, New Zealand. Rates are the number of months (black) and seasons (grey) a dolphin was photo-identified as a proportion of the total number of months and seasons surveys were conducted

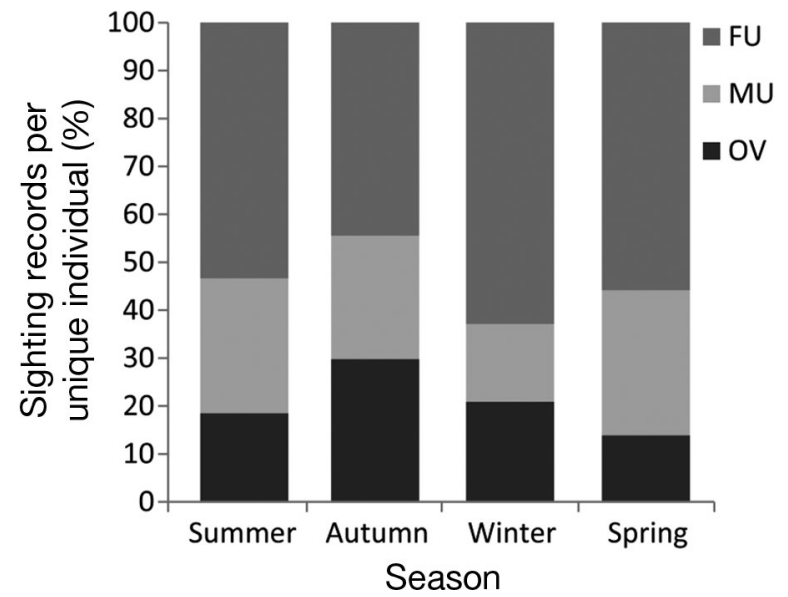

Fig. 7. Seasonal weighted ratio (expressed as a percentage) of the total number of sighting records per unique identified individual bottlenose dolphin Tursiops truncatus at Great Barrier Island, New Zealand. FU: frequent user; MU: moderate user; OV: occasional visitor

Our data showed an interesting pattern in which higher numbers of dolphins were counted during summer $(\mathrm{n}=524)$ and spring $(\mathrm{n}=434)$, but a higher number of unique individuals were sighted in autumn $(\mathrm{n}=116)$ than in any other season (Table 1). This was due to seasonal variations in re-sighting patterns and group dynamics, with a larger proportion of occasional visitors present at GBI during autumn (Fig. 7) in overall smaller group sizes (Fig. 2).

\section{Abundance, temporary emigration and survival estimates}

The mark ratio was estimated from a total of 1423 high-quality photographs collected from 34 surveys during 2011-2013. Of these, 1260 images represented identifiable individuals $(I)$. From this, the mark ratio $\left(P_{\mathrm{m}}\right)$ was estimated at $0.885(\mathrm{SE}=0.012)$, or $88.5 \%$.

The study population could not be considered geographically closed between seasons as some individuals were captured inconsistently across sampling seasons. Therefore, models that incorporated temporary emigration were included in the set of models. As expected, the likelihood ratio test (LRT) rejected models with no temporary emigration (models 5 \& 7 ; Table 3) when tested against models with random $\left(\chi^{2}=58.4, \mathrm{df}=11, \mathrm{p}<0.0001\right)$ and Markovian $\left(\chi^{2}=\right.$ 91.2, $\mathrm{df}=10, \mathrm{p}<0.0001)$ temporary emigration.

Table 2. Number of bottlenose dolphins Tursiops truncatus identified at Great Barrier Island (GBI) and sighted in other regions of the North Island population home range. HGBDC: Hauraki Gulf Bottlenose Dolphin Catalogue

\begin{tabular}{|lccl|}
\hline Region & $\begin{array}{c}\text { GBI individuals } \\
(\mathrm{n}=154)\end{array}$ & $\begin{array}{c}\text { GBI frequent users } \\
(\mathrm{n}=61)\end{array}$ & \multicolumn{1}{c|}{ Source } \\
\hline Inner Hauraki Gulf & 115 & 47 & HGBDC unpubl. data, S. L. Dwyer unpubl. data \\
Bay of Plenty & 89 & 49 & A. M. Meissner unpubl. data \\
Whangarei Coast & 51 & 5 & I. N. Visser unpubl. data \\
\hline
\end{tabular}


Table 3. Model selection for sighting data of bottlenose dolphins Tursiops truncatus at Great Barrier Island, New Zealand, during 2011-2013. Model results are for seasonal Robust Design data (top), and POPAN (below). The lowest AICc value represents the model that has the most support from the data (in bold). Abbreviations: apparent survival $(\phi)$, capture $(p)$, recapture $(c)$ and temporary emigration $(\gamma)$ probabilities, probability of entry $(\beta)$. ML: maximum likelihood; NP: number of parameters; Dev: deviance. The notation (.) indicates that a given parameter was kept constant, $(t)$ indicates that a given parameter was allowed to vary with time, $(s)$ indicates that a parameter was allowed to vary between seasons, and $k$ is a constraint (session $k=$ session $k-1$ ). Notation: $\gamma^{\prime}=\gamma^{\prime \prime}=0$ : no temporary emigration; $\gamma^{\prime}=\gamma^{\prime \prime}$ : random temporary emigration model; $\gamma^{\prime} \neq \gamma^{\prime \prime}$ : Markovian temporary emigration model (following Kendall et al. 1997)

\begin{tabular}{|c|c|c|c|c|c|c|}
\hline Model & $\mathrm{AICc}$ & $\triangle \mathrm{AICc}$ & AICc weight & ML & NP & Dev \\
\hline \multicolumn{7}{|l|}{ Robust Design } \\
\hline $1 \phi(.) \gamma^{\prime}(t, k=k-1) \gamma^{\prime \prime}(t, k=k-1) c=p(t)$ & -765.77 & 0.00 & 0.93362 & 1 & 51 & 1681.36 \\
\hline $2 \phi(t) \gamma^{\prime}(t, k=k-1) \gamma^{\prime \prime}(t, k=k-1) c=p(t)$ & -760.48 & 5.29 & 0.06638 & 0.0711 & 58 & 1671.08 \\
\hline $3 \phi(t) \gamma^{\prime}=\gamma^{\prime \prime}(t, k=k-1) c=p(t)$ & -730.80 & 34.97 & 0 & 0 & 52 & 1714.12 \\
\hline $4 \phi(t) \gamma^{\prime}(.) \gamma^{\prime \prime}() c=.p(t)$ & -711.65 & 54.12 & 0 & 0 & 42 & 1755.18 \\
\hline $5 \phi(t) \gamma=0 C=p(t)$ & -696.46 & 69.31 & 0 & 0 & 41 & 1772.54 \\
\hline $6 \phi(t) \gamma^{\prime}=\gamma^{\prime \prime}() c=.p(t)$ & -696.46 & 69.31 & 0 & 0 & 41 & 1772.54 \\
\hline $7 \phi(.) \gamma=0 \quad c=p(t)$ & -680.26 & 85.51 & 0 & 0 & 38 & 1795.22 \\
\hline $8 \phi(.) \gamma^{\prime}(t, k=k-1) \gamma^{\prime \prime}(t, k=k-1) c=p(s)$ & -610.49 & 155.27 & 0 & 0 & 32 & 1877.83 \\
\hline \multicolumn{7}{|l|}{ POPAN } \\
\hline $9 \phi() p.(t) \beta()$. & 553.15 & 0.00 & 0.87145 & 1 & 12 & 4.46 \\
\hline $10 \phi() p.(t) \beta(t)$ & 557.91 & 4.76 & 0.08067 & 0.0926 & 19 & 0 \\
\hline $11 \phi(t) p(t) \beta()$. & 558.99 & 5.84 & 0.04705 & 0.0540 & 19 & 0 \\
\hline $12 \phi(t) p(t) \beta(t)$ & 567.09 & 13.94 & 0.00082 & 0.0009 & 27 & 0 \\
\hline
\end{tabular}

We first attempted to simplify the capture probability structure by assuming it constant (.) or varying between seasons $(s)$ but models with fully time-varying $(t)$ capture probabilities were strongly favoured. We then tested models with constant apparent survival probability $\phi($.) (models 1,7 \& 8; Table 3). AICc indicated that models with Markovian temporary emigration (models 1, 2, 4 \& 8; Table 3) received more support from the data than models with random emigration (models $3 \& 6$; Table 3 ). The best fitting model assumed constant apparent survival, fully time-varying Markovian temporary emigration and fully time-varying capture probabilities (model 1; Table 3 ) and accounted for $93 \%$ of the AICc weight in the model set. Capture probabilities were variable

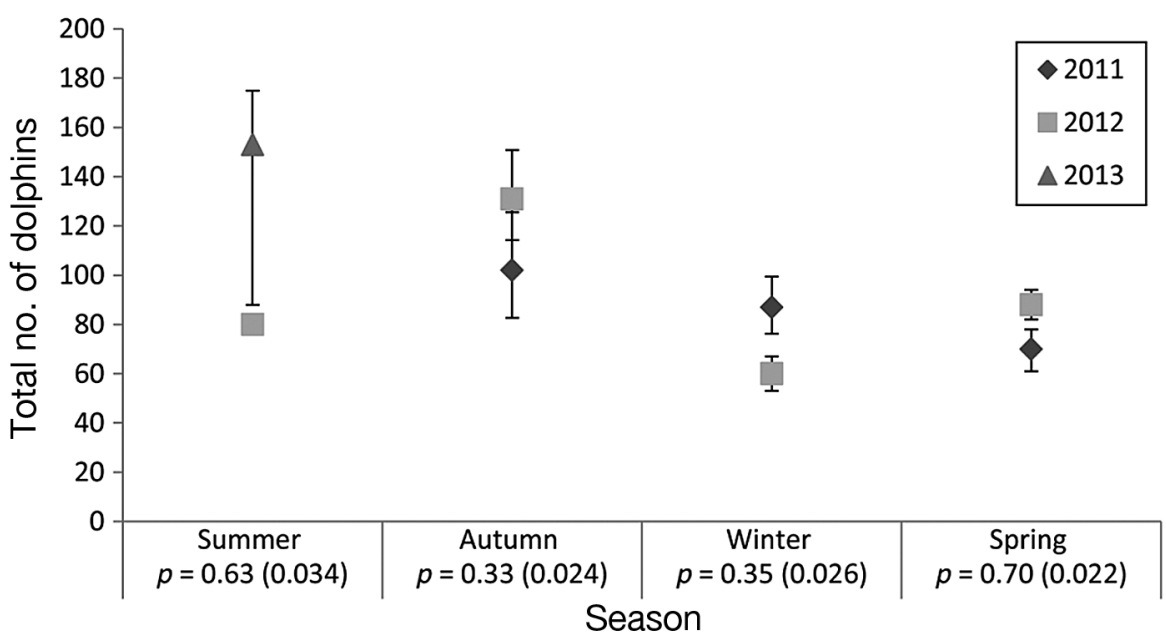

within (range 0.13-0.90) and between (range 0.33$0.70)$ seasons. Overall, spring and summer presented the highest capture probabilities $(0.70, \mathrm{SE}=0.022$, and $0.63, \mathrm{SE}=0.034$, respectively) when compared to autumn $(0.33, \mathrm{SE}=0.024)$ and winter $(0.35, \mathrm{SE}=$ 0.026; Fig. 8). Estimates of abundance also varied; unfortunately, abundance estimates for summer had very low and high standard errors and were deemed unreliable (Fig. 8). Seasonal estimates varied from a low of 60 dolphins (95\% CI $=53-67)$ in winter 2012, to a high of 131 during autumn 2012 (95\% CI = 114-151; Fig. 8), including the correction for unmarked dolphins. Overall, seasonal abundances seemed lower during winter (Fig. 8) when compared to autumn. 
The temporary emigration rates of being absent based on the previous period state of being present $\left(\gamma^{\prime \prime}\right)$ were low and ranged from 0.00 to 0.04 with a peak in winter 2012 and a mean value of 0.01 ( $\mathrm{SE}=$ 0.006; Table 4). The temporary emigration rates of being absent based on the previous period state of also being absent $\left(\gamma^{\prime}\right)$ were high and ranged from 0.03 to 0.75 with a peak in winter 2012 , with a mean of 0.267 ( $\mathrm{SE}=0.140)$. The 'return rate' of temporary emigrants $\left(1-\gamma^{\prime}\right)$ was lower between winter and spring and higher between summer and autumn (Table 4). Our model yielded an apparent survival estimate of 0.918 ( $\mathrm{SE}=0.058,95 \% \mathrm{CI}=0.70-0.98$ ) for adults and juveniles combined, or 0.950 ( $\mathrm{SE}=0.081$, $95 \% \mathrm{CI}=0.40-0.99$ ) for adults only.

\section{POPAN super-population models}

The best fitting model incorporated constant apparent survival, time-varying capture probability and constant probability of entry (model 9; Table 3). This model carried $87 \%$ of the AICc weight. Model averaging was used to estimate the parameters. However, given that this dataset violated goodness of fit tests (Table A1 in the Appendix), only the 'superpopulation' estimate was considered here. This is because we wanted to estimate the total number of dolphins that used GBI from 2011-2013 regardless of their re-sighting pattern (i.e. occasional visitor, moderate user or frequent user). The super-population (i.e. total number of dolphins that visited GBI during the course of the study) was estimated at 171 dolphins $(\mathrm{CI}=162-180)$ including the correction for unmarked animals.

\section{DISCUSSION}

Considering all regions within the home range of a population is important when determining appropriate conservation management. We suggest GBI, a previously undescribed region for delphinids, is a potential hotspot for bottlenose dolphins of the New Zealand North Island population. We report a high level of individual site fidelity, large average group size and high year-round use of the area by groups that predominantly contain neonates and calves. An estimated total of 171 dolphins used this area during the study period. Even within the narrow scope of this focused study at GBI, it is apparent that many individuals spend extended periods of time outside of what has formerly been recognised as the core home range for this population (i.e. BOI/inner Hauraki Gulf). Additionally, it is clear that the GBI region is not simply being used as a corridor to reach other destinations but instead is a key site for at least a part of the North Island population.

Bottlenose dolphins were recorded at GBI during all months of the year, although the probability of encounter depended upon season and depth. A general seasonal onshore-offshore movement between shallow and deeper waters was found to correspond with the same trend identified in BOI, whereby dolphins were distributed in shallower waters during winter and deepest waters during summer (Constantine 2002). A definitive cause for this seasonal shift could not be determined in BOI due to a paucity of data on prey movements, and the same is true for GBI. This warrants further investigation as it may have implications for the general movement patterns of this population and subsequent management plans.

Until now, our understanding of group dynamics within the North Island population has been based on studies conducted solely in BOI. Median and maximum group sizes for BOI have been reported as 8-12 and 60, respectively (Constantine 2002, Tezanos-Pinto 2009). It was therefore surprising to report considerably larger group sizes at GBI (median = 35, maximum = 82). Group size for bottlenose dolphins worldwide is typically reported as 2 to 15 animals (Shane et al. 1986); however, groups of more than 15 individuals are not uncommon in New Zealand waters (Lusseau et al. 2003, Merriman et al. 2009). Although it is unclear why bot-

\begin{tabular}{llcc} 
Season & \multicolumn{2}{c}{$\begin{array}{c}\text { Temporary emigration rates } \\
\left(\gamma^{\prime \prime}\right)\end{array}$} & $\begin{array}{c}\text { Return rate } \\
\left(1-\gamma^{\prime}\right)\end{array}$ \\
\hline Autumn-Winter 2011 & $0.003(0.0001)$ & na & na \\
Winter-Spring 2011 & $0.009(0.001)$ & NE & na \\
Spring-Summer 2011-12 & $0.019(0.005)$ & $0.655(0.025)$ & 0.345 \\
Summer-Autumn 2011-12 & $0.000(0.0008)$ & $0.029(0.004)$ & 0.971 \\
Autumn-Winter 2012 & NE & $0.112(0.019)$ & 0.888 \\
Winter-Spring 2012 & $0.040(0.014)$ & $0.752(0.052)$ & 0.248 \\
Spring-Summer 2012-13 & $0.000(0.0001)$ & $0.047(0.008)$ & 0.953 \\
\hline
\end{tabular}


tlenose dolphins at GBI repeatedly form large groups, one possible explanation may be related to food availability. The south western coast of GBI, where all groups of more than 50 individuals were recorded, is associated with the Colville Channel. This area is characterised by the strongest currents in the Hauraki Gulf (Manighetti \& Carter 1999). Strong upwellings occur at GBI and around the Colville Channel under southeasterly winds (Black et al. 2000) and thus the use of the area by large groups of dolphins may be attributed to a localised increase in biological productivity. Alternatively, GBI may act as a social hub where smaller groups fuse for socialising (S. L. Dwyer unpubl. data). Mann et al. (2000) found bottlenose dolphin group sizes were largest for groups with calves up to 3 mo old, which may also in part explain the formation of large groups at GBI given the high frequency of neonates and calves recorded.

Based on the variable patterns of site fidelity and habitat use observed in BOI (Constantine 2002, Tezanos-Pinto 2009, Hartel et al. 2014, Tezanos-Pinto et al. 2013), we anticipated new individuals would continue to be photo-identified for the duration of the study. The discovery curve reached a plateau after 17 mo of field effort, although a further 8 new individuals were added to the catalogue in the final summer season. We expect that a number of individuals that do not frequently use GBI waters have yet to be identified. Similarly, some dolphins may only visit the area rarely (i.e. transient dolphins), something that has also has been noted for BOI (Tezanos-Pinto et al. 2013).

Overall site fidelity (MSR $=0.33$ ) to the GBI region was high, although re-sighting patterns were variable among individuals. The large proportions of both frequent users and occasional visitors are similar to the variable patterns of residency reported for BOI (Constantine 2002, Tezanos-Pinto 2009). Based on records of GBI individuals outside the study area, it is clear that most bottlenose dolphins recorded at GBI cannot be classified as permanent residents, despite a large proportion of individuals spending considerable periods of time there. Dolphins from BOI are hypothesised to move to the Hauraki Gulf during winter, based on a seasonal low of individuals in BOI (Tezanos-Pinto 2009). However, given the relatively lower abundance and lower number of sighting records for GBI during winter, it seems unlikely that dolphins are congregating there when absent from BOI. Furthermore, peaks in bottlenose dolphin sightings have been reported for autumn in the inner Hauraki Gulf (Berghan et al. 2008). This corresponds with our records of high numbers of occasional visitors at GBI during autumn and the highest return rate for temporary emigrants between summer and autumn. While individuals using BOI are known to frequent GBI waters (Tezanos-Pinto 2011), it is currently unclear what proportion of the North Island population are using GBI waters and to what extent. Future studies should therefore investigate the seasonal movements of North Island bottlenose dolphins across the entire known range to try and discern these apparent trends.

The estimates of temporary emigration were highly variable and sometimes large. Such large fluctuations in abundance and temporary emigration rates indicate variable use of the area through time. Interestingly, our analyses suggested seasonal differences in abundance estimates. Despite the low precision of the summer estimates, our data suggest that abundance is lower during winter and spring. Specifically, abundance estimates varied from a low of 60 dolphins (95\% CI = 53-67) during winter 2012 to a high of 131 (95\% CI = 114-151) during autumn 2012 (excluding summer estimates). This is comparable to a recent study conducted on a coastal population of bottlenose dolphins in Bunbury, Western Australia, that also implemented the Robust Design (Smith et al. 2013); that population also exhibited a seasonal fluctuation in abundance with peak numbers detected in summer and autumn (139 dolphins in autumn 2009) and lower numbers during winter months (63 dolphins in winter 2007). In BOI, a seasonal fluctuation was also apparent with a lower number of dolphins during winter months (TezanosPinto et al. 2013).

In our analysis, models incorporating Markovian temporary emigration were deemed better than both random temporary emigration and models with no temporary emigration. Temporary emigration rates varied between seasons for the best fitting Markovian model, with higher rates during time intervals when animals had been absent in the previous period $\left(\gamma^{\prime}\right)$ than the rates for those present in the previous period $\left(\gamma^{\prime \prime}\right)$. This implies that some individuals leave the study area for multiple seasons but subsequently return. Temporary emigration rates estimated in Bunbury $\left(\gamma^{\prime}=0.34-0.97\right)$ (Smith et al. 2013) were similar to those estimated in this study $\left(\gamma^{\prime}=\right.$ 0.03-0.75) and also varied seasonally. The apparent survival estimated here for adults and juveniles combined $(0.918, \mathrm{SE}=0.058)$ is marginally lower than the estimate for adults only $(0.950, \mathrm{SE}=0.081)$. This is consistent with studies conducted in other areas that reported lower survival rates for juveniles (Stolen \& 
Barlow 2003). Additionally, a recently reported mortality event at GBI involved a fatal boat strike to a juvenile bottlenose dolphin (Dwyer et al. 2014). Adult survival estimates for GBI are slightly higher than those reported for BOI $(0.928, \mathrm{SE}=0.008)$ for $1997-$ 2006 (Tezanos-Pinto et al. 2013) but similar to Bunbury $(0.95, \mathrm{SE}=0.02)$ for 2007-2009 (Smith et al. 2013).

In Bunbury, seasonal fluctuations in abundance were explained by an influx of adult males into the study area during the breeding season (summer/ autumn) and their subsequent departure during the non-breeding months (Smith et al. 2013). Breeding is also seasonal in BOI (Constantine 2002, TezanosPinto 2009) so it is possible that a similar situation occurs in GBI waters, where the sex of most dolphins is currently largely unknown, especially males and non-reproductive females.

We believe the importance of the GBI region has likely been overlooked at least partly as a consequence of the user-pays research system. Since core long-term research on the North Island population has primarily focused only on areas where bottlenose dolphins are subject to tourism activities, it remains unclear how long and to what extent GBI and potentially other regions of unstudied coastline have been important for this population. We therefore strongly recommend that other poorly studied areas within the home range be examined so their relative importance in the context of the North Island population can be assessed. We also recommend further studies to estimate abundance, in addition to reproductive and demographic parameters, across the entire range of the North Island population. This is particularly relevant following the decline in local abundance of bottlenose dolphins in BOI, where it is unclear whether the decline is due to mortality, low recruitment, emigration or a combination of these (TezanosPinto et al. 2013).

From a management perspective, we suggest commercial tourism should not be allowed to target marine mammals in the GBI region until further research has been conducted into the relative importance of the area for the North Island population. GBI also offers a unique opportunity as a control site to compare against other regions of the home range that are heavily exposed to tourism.

\section{CONCLUSION}

For management to be effective, a comprehensive approach including the entire home range of a popu- lation is required, especially when considering wideranging species such as marine mammals. This is arguably constrained if the majority of field-based research is funded via user-pays systems. We therefore highlight the need for researchers, managers and funding agencies to maintain an open outlook on the population of interest as a whole when conducting or funding research.

Acknowledgements. S.L.D. thanks the Great Barrier Island local community, in particular the Motu Kaikoura Trust, Great Barrier Island Marine Radio, F. Christian, C. Flinn, R. Gibson, A. Jones, E. Pratt, J. Scarlett, W. Scarlett and M. Tucker. Special thanks go to all who assisted in the field. N. de la Brosse and K. Hupman provided additional photographs from the inner Hauraki Gulf. We acknowledge N. Wiseman and the late K. Algie who contributed to the Hauraki Gulf Bottlenose Dolphin Catalogue. Thanks to D. Clement and W. Jiang (Cawthron Institute) for providing the AVHRR Oceans Pathfinder SST data obtained from the Physical Oceanography Distributed Active Archive Center (PO.DAAC) at the NASA Jet Propulsion Laboratory, Pasadena, California, USA (http://podaac.jpl.nasa.gov). Data logging software was free to use from CyberTracker Conservation (http://cybertracker.org). Funding was provided by the New Zealand Department of Conservation (Auckland Conservancy), Massey University and Golden Contracting Whangaparaoa. S.L.D. is the recipient of a Massey University Institute of Natural and Mathematical Sciences doctoral scholarship. I.N.V. was funded by the Orca Research Trust. We thank the managing editor and the reviewers who provided constructive feedback that enhanced the quality of this work.

\section{LITERATURE CITED}

Baker CS, Chilvers BL, Constantine R, Du Fresne SP, Mattlin RH, Van Helden A, Hitchmough RA (2010) Conservation status of New Zealand marine mammals (suborders Cetacea and Pinnipedia), 2009. NZ J Mar Freshw Res 44: 101-115

Bearzi G, Fortuna C, Reeves R (2012) Tursiops truncatus (Mediterranean subpopulation). In: IUCN 2013. IUCN Red List of Threatened Species. Version 2013.1. www. iucnredlist.org (accessed 13 July 2013)

Bejder L, Dawson SM, Harraway JA (1999) Responses by Hector's dolphins to boats and swimmers in Porpoise Bay, New Zealand. Mar Mamm Sci 15:738-750

Berghan J, Algie KD, Stockin KA, Wiseman N, Constantine R, Tezanos-Pinto G, Mourão F (2008) A preliminary photoidentification study of bottlenose dolphin (Tursiops truncatus) in Hauraki Gulf, New Zealand. NZ J Mar Freshw Res 42:465-472

Beyer HL (2012) Geospatial Modelling Environment (Version 0.7.2.0). Available at http://spatialecology.com/gme

> Black KP, Hume M, Bell RG, Oldman JW, Carter GS, Hume TM (2000) Features of 3-dimensional barotropic and baroclinic circulation in the Hauraki Gulf, New Zealand. NZ J Mar Freshw Res 34:1-28

Burnham KP, Anderson DR (2004) Multimodel inference. Understanding AIC and BIC. Sociol Methods Res 33: 261-304 
Burnham KP, Anderson DR, White GC, Brownie C, Pollock $\mathrm{KH}$ (1987) Design and analysis of fish survival experiments based on release-recapture data. American Fisheries Society Monograph, Bethesda, MD

> Cagnazzi DDB, Harrison PL, Ross GJB, Lynch P (2011) Abundance and site fidelity of Indo-Pacific humpback dolphins in the Great Sandy Strait, Queensland, Australia. Mar Mamm Sci 27:255-281

- Cantor M, Wedekin LL, Daura-Jorge FG, Rossi-Santos M, Simões-Lopez P (2012) Assessing population parameters and trends in Guiana dolphins (Sotalia guianensis): an eight-year mark-recapture study. Mar Mamm Sci 28: 63-83

Chilvers BL (2008) New Zealand sea lions Phocarctos hookeri and squid trawl fisheries: bycatch problems and management options. Endang Species Res 5:193-204

> Chilvers BL, Wilkinson IS, Duignan PJ, Gemmell NJ (2005) Summer foraging areas for lactating New Zealand sea lions Phocarctos hookeri. Mar Ecol Prog Ser 304:235-247

Choquet R, Reboulet AM, Lebreton JD, Gimenez O, Pradel R (2005) U-CARE 2.2 (Utilities-CApture-REcapture) user's manual. CEFE, Montpellier

> Clapham PJ, Young SB, Brownell RL Jr (1999) Baleen whales: conservation issues and the status of the most endangered populations. Mammal Rev 29:37-62

Constantine R (2001) Increased avoidance of swimmers by wild bottlenose dolphins (Tursiops truncatus) due to long-term exposure to swim-with-dolphin tourism. Mar Mamm Sci 17:689-702

Constantine R (2002) The behavioural ecology of the bottlenose dolphins (Tursiops truncatus) of northeastern New Zealand: a population exposed to tourism. PhD thesis, University of Auckland, Auckland

Constantine R, Baker CS (1997) Monitoring the commercial swim-with-dolphin operations in the Bay of Islands. Science for Conservation 56, Department of Conservation, Wellington

Constantine R, Brunton DH, Baker CS (2003) Effects of tourism on behavioural ecology of bottlenose dolphins of northeastern New Zealand. DOC Science Internal Series 153, Department of Conservation, Wellington

> Constantine R, Brunton DH, Dennis T (2004) Dolphinwatching tour boats change bottlenose dolphin (Tursiops truncatus) behaviour. Biol Conserv 117:299-307

Cooch E, White BN (2011) Program MARK. 'A gentle introduction'. Colorado State University, Fort Collins, CO

> Currey RJC, Dawson SM, Slooten E (2009) An approach for regional threat assessment under IUCN Red List criteria that is robust to uncertainty: the Fiordland bottlenose dolphins are critically endangered. Biol Conserv 142: 1570-1579

Currey RJC, Dawson SM, Slooten E (2011) Tursiops truncatus (Fiordland subpopulation). In: IUCN 2013. IUCN Red List of Threatened Species. Version 2013.1. Available at www.iucnredlist.org (accessed 13 July 2013)

> Dwyer SL, Kozmian-Ledward L, Stockin KA (2014) Shortterm survival of severe propeller strike injuries and observations on wound progression in a bottlenose dolphin. NZ J Mar Freshw Res 48:294-302

> Gormley AM, Dawson SM, Slooten E, Bräger S (2005) Capture-recapture estimates of Hector's dolphin abundance at Banks Peninsula, New Zealand. Mar Mamm Sci 21: 204-216

Hammond PS, Bearzi G, Bjørge A, Forney K and others (2012) Tursiops truncatus. In: IUCN 2012. IUCN Red List of Threatened Species Version 2012.1. Available at www. iucnredlist.org/details/22563/0 (accessed 28 July 2013)

Hartel EF, Constantine R, Torres LG (2014) Changes in habitat use patterns by bottlenose dolphins over a 10 -year period render static management boundaries ineffective. Aquat Conserv Mar Freshw Ecosyst, doi:10.1002/aqc.2465

Helweg DA (1998) Automating the acoustic monitoring of New Zealand waters for migrating humpback whales (Megaptera novaeangliae). Technical Report 1765. Space and Naval Warfare Systems Center, San Diego, CA

Hitchmough RA (2002) New Zealand Threat Classification System lists 2002. Threatened Species Occasional Publication 23. Department of Conservation, Wellington

Hitchmough RA, Bull L, Cromarty P (2007) New Zealand Threat Classification System lists 2005. New Zealand Department of Conservation, Wellington

Hooker SK, Gerber LR (2004) Marine reserves as a tool for ecosystem-based management: the potential importance of megafauna. Bioscience 54:27-39

Huggins RM (1991) Some practical aspects of a conditional likelihood approach to capture experiments. Biometrics 47:725-732

Jolly GM (1965) Explicit estimates from capture-recapture data with both birth and immigration, a stochastic model. Biometrika 52:225-247

Kendall WL (2004) Coping with unobservable and misclassified states in capture-recapture studies. Anim Biodivers Conserv 27:97-107

Kendall WL, Pollock KH, Brownie C (1995) A likelihoodbased approach to capture recapture estimation of demographic parameters under the robust design. Biometrics 51:293-308

Kendall WL, Nichols JD, Hines JE (1997) Estimating temporary emigration using capture-recapture data with Pollock's robust design. Ecology 78:563-578

Kibblewhite AC, Denham RN, Barnes DJ (1967) Unusual low-frequency signals observed in New Zealand waters. J Acoust Soc Am 41:644-655

Komdeur J (1996) Breeding of the Seychelles magpie robin Copsychus sechellarum and implications for its conservation. Ibis 138:485-498

> Lundquist D, Gemmell NJ, Würsig B (2012) Behavioural responses of dusky dolphin groups (Lagenorhynchus obscurus) to tour vessels off Kaikoura, New Zealand. PLoS ONE 7:e41969

- Lusseau D (2003) Effects of tour boats on the behavior of bottlenose dolphins: using Markov chains to model anthropogenic impacts. Conserv Biol 17:1785-1793

Lusseau D, Schneider K, Boisseau OJ, Haase P, Slooten E, Dawson SM (2003) The bottlenose dolphin community of Doubtful Sound features a large proportion of longlasting associations. Can geographic isolation explain this unique trait? Behav Ecol Sociobiol 54:396-405

Mackay KA, Mackay EJ, Neil HL, Mitchell JS, Bardsley SA (2012) Hauraki Gulf. NIWA Chart, Miscellaneous Series 91. Available at www.niwa.co.nz/our-science/oceans/ bathymetry

> Manighetti B, Carter L (1999) Across-shelf sediment dispersal, Hauraki Gulf, New Zealand. Mar Geol 160:271-300

> Mann J (1999) Behavioural sampling methods for cetaceans: a review and critique. Mar Mamm Sci 15:102-122

- Mann J, Connor R, Barre L, Heithaus M (2000) Female reproductive success in bottlenose dolphins (Tursiops sp.): life history, habitat, provisioning, and group-size effects. Behav Ecol 11:210-219 
Martinez E, Orams MB, Stockin KA (2010) Swimming with an endemic and endangered species: effects of tourism on Hector's dolphins in Akaroa Harbour, New Zealand. Tourism Rev Int 14:99-115

McDonald MA (2006) An acoustic survey of baleen whales off Great Barrier Island, New Zealand. NZ J Mar Freshw Res 40:519-529

- Merriman MG, Markowitz TM, Harlin-Cognato AD, Stockin KA (2009) Bottlenose dolphin (Tursiops truncatus) abundance, site fidelity, and group dynamics in the Marlborough Sounds, New Zealand. Aquat Mamm 35: 511-522

> Neumann DR, Orams MB (2006) Impacts of ecotourism on short-beaked common dolphins (Delphinus delphis) in Mercury Bay, New Zealand. Aquat Mamm 32:1-9

Nichols JD (2005) Modern open-population capture-recapture models. In: Amstrup SC, McDonald TL, Manly BFJ (eds) Handbook of capture-recapture analysis. Princeton University Press, Princeton, NJ, p 88-123

Norgrove K, Jordan C (2006) Economic influences on the future of Great Barrier Island. Report to City Planning, Auckland City Council

> Parra GJ, Corkeron PJ, Marsh H (2006) Population sizes, site fidelity and residence patterns of Australian snubfin and Indo-Pacific humpback dolphins: implications for conversation. Biol Conserv 129:167-180

Pollock KH (1982) A capture-recapture design robust to unequal probability of capture. J Wildl Manag 46:752-757

R Development Core Team (2013) R: a language and environment for statistical computing. R Foundation for Statistical Computing, Vienna. Available at www.r-project.org

> Rayment W, Webster T (2009) Observations of Hector's dolphins (Cephalorhynchus hectori) associating with inshore fishing trawlers at Banks Peninsula, New Zealand. NZ J Mar Freshw Res 43:911-916

Richter C, Dawson S, Slooten E (2006) Impacts of commercial whale watching on male sperm whales at Kaikoura, New Zealand. Mar Mamm Sci 22:46-63

Schwarz CJ, Arnanson AN (1996) A general methodology for the analysis of capture-recapture experiments in open populations. Biometrics 52:860-873

Shane SH (1990) Behavior and ecology of the bottlenose dolphin at Sanibel Island, Florida. In: Leatherwood S, Reeves RR (eds) The bottlenose dolphin. Academic Press, San Diego, CA, p 245-265

> Shane SH, Wells RS, Würsig B (1986) Ecology, behavior and social organization of the bottlenose dolphin: a review. Mar Mamm Sci 2:34-63

Slooten E (2007) Conservation management in the face of uncertainty: effectiveness of four options for managing Hector's dolphin bycatch. Endang Species Res 3:169-179

Slooten E, Lad F (1991) Population biology and conservation of Hector's dolphin. Can J Zool 69:1701-1707

Slooten E, Dawson S, Rayment W, Childerhouse S (2006) A new abundance estimate for Maui's dolphin: What does it mean for managing this critically endangered species? Biol Conserv 128:576-581

Smith HC, Pollock KH, Waples K, Bradley S, Bejder L (2013) Use of the Robust Design to estimate seasonal abundance and demographic parameters of a coastal bottlenose dolphin (Tursiops truncatus) population. PLoS ONE 8:e76574
Stanley TR, Burnham KP (1999) A closure test for timespecific capture-recapture data. Environ Ecol Stat 6: 197-209

Steventon J, Liebenberg L, Derbecker M, Bapat V (2002) CyberTracker Conservation. Available at http://cybertracker.org

> Stockin KA, Lusseau D, Binedell V, Wiseman N, Orams MB (2008a) Tourism affects the behavioural budget of the common dolphin Delphinus sp. in the Hauraki Gulf, New Zealand. Mar Ecol Prog Ser 355:287-295

Stockin KA, Pierce GJ, Binedell V, Wiseman N, Orams MB (2008b) Factors affecting the occurrence and demographics of common dolphins (Delphinus sp.) in the Hauraki Gulf, New Zealand. Aquat Mamm 34:200-211

> Stolen MK, Barlow J (2003) A model life table for bottlenose dolphins (Tursiops truncatus) from the Indian River Lagoon System, Florida, USA. Mar Mamm Sci 19:630-649

Tezanos-Pinto G (2009) Population structure, abundance and reproductive parameters of bottlenose dolphins (Tursiops truncatus) in the Bay of Islands (Northland, New Zealand). PhD thesis, University of Auckland, Auckland

Tezanos-Pinto G (2011) Photo-identification and re-sighting rates of bottlenose dolphins (Tursiops truncatus) in the Hauraki Gulf and abundance along the north-eastern coast of the North Island. Department of Conservation Internal Report NHS-09-01-05-03, Bay of Islands Area Office

- Tezanos-Pinto G, Baker CS, Russell K, Martien K and others (2009) A worldwide perspective on the population structure and genetic diveristy of bottlenose dolphins (Tursiops truncatus) in New Zealand. J Hered 100:11-24

- Tezanos-Pinto G, Constantine R, Brooks L, Jackson JA, Mourão F, Wells S, Baker CS (2013) Decline in local abundance of bottlenose dolphins (Tursiops truncatus) in the Bay of Islands, New Zealand. Mar Mamm Sci 29: E390-E410

Thompson FN, Abraham ER, Berkenbusch K (2013) Common dolphin (Delphinus delphis) bycatch in New Zealand commercial trawl fisheries. PLoS ONE 8:e64438

> White GC, Burnham KP (1999) Program MARK: Survival estimation from populations of marked animals. Bird Study 46(Suppl):S120-S138

- Williams JA, Dawson SM, Slooten E (1993) The abundance and distribution of bottlenosed dolphins (Tursiops truncatus) in Doubtful Sound, New Zealand. Can J Zool 71: 2080-2088

Williams BK, Nichols JD, Conroy MJ (2002) Analysis and management of animal populations. Academic Press, San Diego, CA

- Wilson B, Hammond PS, Thompson PM (1999) Estimating size and assessing trends in a coastal bottlenose dolphin population. Ecol Appl 9:288-300

> Wright $\mathrm{PC}$, Johnson SE, Irwin MT, Jacobs R and others (2008) The crisis of the critically endangered greater bamboo lemur (Prolemur simus). Primate Conserv 23: 5-17

Würsig B, Jefferson TA (1990) Methods of photo-identification for small cetaceans. In: Hammond PS, Mizroch SA, Donovan GP (eds) Individual recognition of cetaceans: use of photo-identification and other techniques to estimate population parameters. Rep Int Whal Comm Spec Issue 12:43-52 


\section{Appendix}

Table A1. Results of goodness of fit test conducted in U-CARE 2.02 for the seasonal dataset in a Cormack-Jolly-Seber framework for bottlenose dolphins Tursiops truncatus at Great Barrier Island, New Zealand

\begin{tabular}{|lcccc|}
\hline & TEST 2.CT & TEST 2.CL & TEST 3.SM & TEST 3.SR \\
\hline Seasonal dataset: & $\chi^{2}=41.2$ & $\chi^{2}=14.01$ & $\chi^{2}=51.3$ & $\chi^{2}=35.1$ \\
& $\mathrm{p}<0.0005$ & $\mathrm{p}=0.02$ & $\mathrm{p}<0.005$ & $\mathrm{p}<0.0005$ \\
& Stat $=-5.4$ & & & Stat $=4.3$ \\
& $\mathrm{p}<0.0005$ & & $\mathrm{p}<0.0005$ \\
Sum of tests: & $\chi^{2}=141.8$ & & \\
& $\mathrm{p}<0.005$ & & & \\
\hline
\end{tabular}

Editorial responsibility: Andrew Read, Beaufort, North Carolina, USA
Submitted: August 8, 2013; Accepted: May 16, 2014 Proofs received from author(s): August 22, 2014 